\section{Feministisen tulevaisuuden käsikirja kaikille}

bell hooks (2020). Mies tahtoo muuttua. Miehet, maskuliinisuus ja rakkaus. Suomentanut Tapani Kilpeläinen. niin \& näin. 173 sivua.

\section{YHDYSVALTALAINEN GLORIA} Jean Watkins (1952-), kirjailijanimeltään bell hooks, kuuluu aikamme tunnetuimpiin feministiteoreetikoihin. Hänen kolmas suomennettu teoksensa, Mies tahtoo munttua, on yleistajuinen ja ajatuksia herättävä feminististen arvojen puolustuspuhe. Sen keskeisen argumentin voi tiivistää seuraavasti: mitä enemmän miehet ovat kosketuksissa omiin tunteisiinsa feministisen ajattelun avulla, sitä paremmin kaikki voivat.

Kirjassaan hooks pyrkii vastaamaan tarpeeseen luoda emotionaalisesti yhä ehjempi yhteiskunta tarjoamalla uudenlaisen kollektiivisen tavan muuttaa sukupuoliin kiinnittyvää ajattelua. Hän punoo teoksensa punaisen langan kollektiivisen ajatusten muutoksen, arvojen vallankumouksen, varaan. Kasvatuksellisesti tällainen arvojen muutoksen haaste ei koske ainoastaan lasten kasvattamista vaan on ennen kaikkea aikuisen itsensä kasvamisen ja kasvattamisen paikka. Aikuiskasvatuksellisesti teos tarjoaa tarpeellisen kriittisen ajattelun käsikirjan sukupuolta koskevaan keskusteluun ja tiedostamattomien käyttäytymistä ohjaavien stereotypioiden tarkasteluun.

\section{PATRIARKAATTI}

\section{YMPÄRILLÄMME}

Teoksen keskeinen käsite on patriarkaatti, jonka hooks määrittelee valkoista ylivaltaa kannattavaksi, kapitalistiseksi poliittis-yhteiskunnalliseksi järjestelmäksi. Sen tyypillisiä piirteitä ovat valkoihoisten miesten käsiin keskittyvän vallanjaon ylläpitäminen ja alistamisen kulttuuri.

Feminismin hooks taas määrittelee patriarkaatin vastavoimaksi. Se voi tarjota mahdollisuuden perustavaan kollektiivisen ajattelun muutokseen, joka on mahdollisuus rakentaa kaikille sukupuolille tasa-arvoista ja emotionaalisesti vapautunutta yhteiskuntaa. Tiedostamattoman sukupuolisen ajattelun ongelmakohtia eivät siten hooksin mukaan ole niinkään sukupuolet sinänsä, vaan binäärisen eli kaksijakoisen sukupuolijaottelun ilmentymismuodot ja niitä ylläpitävä kasvatus patriarkaattisessa yhteiskunnassa.

Poliittis-yhteiskunnallisena järjestelmänä patriarkaatti on hooksille hienovarainen vallan väline. Patriarkaattisia arvoja voivat kannattaa ja uudistaa niin korkeasti koulutetut yksinhuoltajaäidit kuin konservatiiviset miesjohtajat, joten patriarkaatin tulevaisuus ei ole vain yhden sukupuolen käsissä.

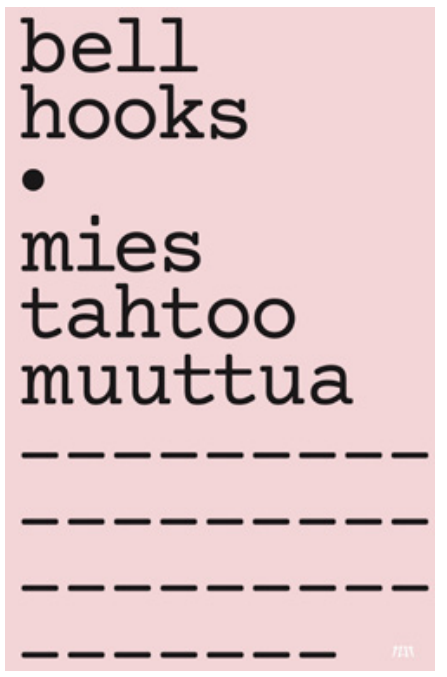

hooks tekee ansiokkaan työn määritellessään yksiin kansiin kattavasti patriarkaattisen yhteiskuntajärjestelmän peruspiirteet ja sen ilmenemismuodot niin työssä, perhe-elämässä ja seksuaalisuudessa kuin kasvatuksessakin. Vaikka teos punoutuu hooksin omiin kokemuksiin patriarkaatista 1950-2000-lukujen amerikkalaisessa kulttuurissa, sen kuvaaman patriarkaattisen arvomaailman läsnäolo on nähtävissä suomalaisessakin yhteiskunnassa.

\section{KOHTI FEMINISTISTÄ}

MASKULIINISUUTTA

Intersektionaalisuus, feminismin nykyisen kolmannen aallon muoto, joka sisällyttää feminismin piiriin kaikkien sorrettujen ryhmien oikeudenmukaisuuden tavoittelun, on hooksin teoksessa mukana vain rotukysymyksissä. Muut sukupuolen ja seksuaalisuuden muodot, kuten intersukupuolisuus ja transihmiset, taas puuttuvat kirjan kuvauksesta kokonaan. hooksin tarkoitus 


\section{MEIDÄN TÄYTYY YHDESSÄ RAKENTAA YHTEISKUNTAA, JOSSA TUNTEIDEN NÄYTTÄMINEN JA KOKEMINEN ON KAIKILLE}

KUULUVA IHMISOIKEUS.

lienee kuvata heteronormatiivisen yhteiskuntajärjestelmän purkamista binäärisistä sukupuolirooleista käsin, mutta sukupuolen ja seksuaalisuuden monimuotoisuus olisi nähdäkseni ansainnut huomiota teoksessa vähintäänkin binääristä ajattelua haastavana ilmiönä.

Kirja keskittyy miesten muuttumisen mahdollisuuksiin ja heidän tunteidensa vapauttamiseen patriarkaattisen yhteiskunnan säätelyltä. hooks pitää keskeisenä ongelmana patriarkaattisen maskuliinisuuden ihannetta, joka saa miehet tukahduttamaan tunteensa. Emotionaalisen tukahtuneisuuden vuoksi miehet irtoavat aikuisiksi kasvaessaan ihmisenä olemisen inhimillisistä perustoista, kuten kyvystä tuntea emotionaalista läheisyyttä ja rakastaa, mikä aiheuttaa sukupuolista väkivaltaa ja sukupuolten tunneelämän tyytymättömyyttä. hooksin ratkaisu on näennäisesti yksinkertainen mutta radikaali toimi: miehiä täytyy rakastaa, jotta he oppivat rakastamaan. Miesten täytyy siten oppia feministisen maskuliinisuuden taito. Ja tämän myötä meidän kaikkien täytyy muuttua.

\section{ARVOJEN MUUTOKSEN ASKELEET}

hooksin teos muistuttaa aikuiskasvatuksen ammattilaisia sukupuoleen kytkeytyvän valtakulttuurin olemassaolosta. Ärrioikeistolaisten, ärikonservatiivisten ja rasististen voimien noustessa on tärkeää ymmärtää oikeistopopulististen ja patriarkaattisen arvojen yhteys. Kuva vahvasta, patriarkaattista maskuliinisuutta huokuvasta johtajasta pitää yllä kaikille haitallista alistamisen ja hallitsemisen kulttuuria. Kirja tarjoaa lukukokemuksena tarpeellisia patriarkaatin haitallisuutta ja monitahoisuutta valottavia kriittisiä huomioita sekä aineksia omaa toimintaa ohjaavien arvojen itsereflektioon.

Omiin silmiini teos ei aukea kehotuksena, jonka mukaan vain naisten pitäisi tarjota miehille kasvuun sopivat olot, vaan 'me', joihin hooks toistuvasti viittaa, tarkoittanee lukijoita laajempana kollektiivina. hooks muistaa liki jokaisen luvun lopussa toki nostaa esiin feministisiä arvoja omaksuneiden miesten arvostuksen ja vaalinnan, mutta silti teosta voi ainakin tulkita myös kaikille sukupuolille sopivana kutsuna muuttaa patriarkaattisen maskuliinisuuden suuntaa.

Itse tulkitsen kirjailijan keskeiseksi sanomaksi sen, että meidän täytyy yhdessä rakentaa yhteiskuntaa, jossa tunteiden näyttäminen ja kokeminen ei kiinnity ihmisen oletettuun sukupuoleen vaan on kaikille tasapuolisesti taattava ihmisoikeus. Näin meille kaikille tarjoutuu mahdollisuus elää mielekästä ja yhä tunnerikkaampaa elämää. Sukupuolisidonnaisuudesta vapaa oikeus kokea tunteita pitää ihmisen lähellä tietoisuutta itsestään inhimillisenä olentona ja auttaa empatian taidon harjoittamisessa. Tarvitsemme kasvattajina teoksen kaltaisia filosofisia pohdintoja ja utooppisia kuvauksia toisenlaisen maailman mahdollisuuksista, jotta voimme nykyistä estottomammin kuvitella, millainen yhteiskunta vielä voisi olla.

Teos on ajattelemaan kannustava, tunteita herättävä ja kattava kokoelma binärisen sukupuolijaottelun seurauksista ja sen inhimillisestä järjettömyydestä. Se kutsuu lukijansa kysymään, millaisessa yhteiskunnassa todella haluamme elää ja millaisia arvoja omalla toiminnallamme haluamme uudistaa - ja miksi.

Tapani Kilpeläisen suomennos ja teoksen tuominen laajemmin suomalaisten lukijoiden käsiin on arvokas työ itsessään. Itsenäisenä tekstinä suomennos ei kuitenkaan täysin tavoita hooksin omaa, persoonallista kirjoittajan ääntä vaan jättää lukijan takeltelemaan alkukielelle ominaisten mutta suomeksi huonosti taipuvien lauserakenteiden kanssa. Ymmärtäminen on siksi toisinaan työlästä, vaikka teoksen sisältö itsessään ansaitsee paikkansa kriittisen kasvattajan lukemistossa.

\section{JOHANNA KALLIO \\ KM, apurahatutkija \\ kasvatustieteiden ja kulttuurin \\ tiedekunta \\ Tampereen yliopisto \\ (i) https://orcid.org/0000-0002- 2820-5177}

